\title{
33
}

\section{Treatment of Perianal Crohn Disease Fistulae}

\author{
Mark T. Osterman and Gary R. Lichtenstein*
}

\section{Introduction}

Crohn disease is a chronic inflammatory disorder that may affect any part of the bowel, from mouth to anus. Three main patterns of disease have been described: inflammatory, structuring, and fistulizing. Fistulae were first described by Crohn et al. in 1932 in their initial description of regional ileitis [1]. Although no perianal lesions were noted by these authors, perianal fistulae were observed in association with Crohn disease soon after by Bissell [2]. Fistulae are now recognized as a common and important aspect of this disease. The treatment of perianal Crohn fistulae has improved greatly over the last ten years as new medical therapies, especially infliximab, have been developed. The purpose of this chapter is to discuss our current knowledge of perianal fistulizing Crohn disease, focusing on its medical management.

\section{Background}

\section{Classification}

Perianal fistulae historically have been classified in a variety of ways. The most clinical useful way to classify fistulae was recently proposed by the American Gastroenterological Association in a position statement and technical review on perianal Crohn disease [3, 4]. They stratify perianal fistulae into two groups: simple and complex. Simple fistulae are low, i.e. below the dentate line, and have a superficial, low intersphincteric, or low transsphincteric origin. These fistulae also have a single external opening, have no associated pain or fluctuation to suggest an abscess, and have no evidence of a rectovaginal fistula or anorectal stricture. Complex fistulae, on the other hand, are high in origin (high intersphincteric, high transsphincteric, or suprasphincteric), may have multiple external openings, may have associated pain or fluctuation to suggest an abscess, and may have evidence of a rectovaginal fistula or anorectal stricture. The distinction between the two types of perianal fistula is clinically important, not only because the management varies, but also because several studies have demonstrated higher rates of healing with simple fistulae [ $[-5]$ ]

\footnotetext{
*Hospital of the University of Pennsylvania, University of Pennsylvania School of Medicine, Division of Gastroenterology, 3rd Floor Ravdin Building, 3400 Spruce Street, Philadelphia, PA 19104-4283, Phone: 215-662-4310 or 215-349-8222, Fax: 215-349-5915, Email: grl@uphs.upenn.edu
} 


\section{Pathogenesis}

The transmural nature of the inflammation that typifies Crohn disease predisposes patients to fistula formation. Although the pathogenesis of perianal fistulae is not known precisely, two mechanisms seem plausible [9]. Perianal fistulae may develop locally as deep penetrating ulcers in the anus or rectum, which then extend over time as feces is forced into the ulcers during defecation [10]. Alternatively, these fistulae may develop after anal gland infections or abscesses [11]. Since some of the anal glands penetrate into the intersphincteric space, infection in this space can readily extend to the external anal sphincter or skin.

\section{Natural History}

The reported incidence of fistulae in Crohn disease patients ranges from $17 \%$ to $43 \%$ in referralcenter-based case series [12-21]. Only two population-based studies examining the natural history of Crohn fistulae have been published to date [22, 23]. The first, a study by Hellers et al. included 826 patients diagnosed with Crohn disease in Stockholm County, Sweden, from 1955 to 1974 and observed a $23 \%$ cumulative incidence of perianal fistulae [22]. The authors noticed that the frequency of perianal fistulae increased as the inflammatory disease became more distal, with a $12 \%$ incidence in ileal disease, $15 \%$ in ileocolonic disease, $41 \%$ in colonic without rectal disease, and $92 \%$ in colonic with rectal disease. More recently, Schwartz et al. examined 176 patients diagnosed with Crohn disease in Olmsted County, Minnesota, from 1970 to 1993 and found a cumulative incidence of at least one fistula (at any site) of $21 \%$ at 1 year, $26 \%$ at 5 years, $33 \%$ at 10 years, and $50 \%$ at 20 years [23]. The corresponding cumulative incidences of at least one perianal fistula were $12 \%$ at 1 year, $15 \%$ at 5 years, $21 \%$ at 10 years, and $26 \%$ at 20 years. Taken collectively, fistulae were located as follows: $54 \%$ perianal, $24 \%$ enteroenteric, $9 \%$ rectovaginal, $6 \%$ enterocutaneous, $3 \%$ enterovesical, and $3 \%$ entero-intraabdominal. Interestingly, $45 \%$ of patients developed a perianal fistula before or at the time of diagnosis of Crohn disease, an observation first noted by Gray et al. in 1965 [24] and also seen in the study by Hellers et al. [22]. This observation highlights the frequent difficulties encountered in attempting to diagnose Crohn disease in patients with isolated perianal disease.

The clinical course of perianal fistulae depends somewhat on their complexity. Simple fistulae may heal spontaneously in up to $50 \%$ of cases [16, 25], whereas complex fistulae rarely heal spontaneously [26]. A number of studies have demonstrated that simple perianal fistulae tend to heal more completely and recur less than complex fistulae [6, 8, 25, 27, 28].

\section{Diagnosis}

Since healing rates seem to decrease when fistulae transform from simple to complex, it is tantamount to recognize and treat perianal Crohn fistulae as soon as symptoms manifest themselves. Thus, fistula location and extent must be accurately ascertained prior to commencing therapy. Unfortunately, digital rectal examination alone is not sufficient in this capacity, with accuracy as low as 62\% [29]. Fortunately, a variety of other modalities exist, including fistulography, pelvic CT, pelvic magnetic resonance imaging (MRI), anorectal endoscopic ultrasound (EUS), and examination under anesthesia (EUA). Fistulography, which may cause significant patient discomfort and more importantly may disseminate septic fistula content, has a reported diagnostic accuracy of $16-50 \%$, which is too low to be clinical useful [30-34. Similarly, CT, with its limited diagnostic accuracy of 24-60\%, is also not particularly useful [35-41]. Pelvic MRI, on the contrary, represents a vast improvement with a reported diagnostic accuracy of $76-100 \%$ and is often used to delineate anorectal and pelvic anatomy [42-50]. Anorectal EUS is also a clinically useful diagnostic modality with diagnostic accuracy ranging from $56-100 \%$ [41, 49, 51-56. Of note, both pelvic MRI and anorectal EUS have been found to change surgical management in 
$10-15 \%$ of cases [44-50, 56]. EUA performed by an experienced colorectal surgeon has long been considered the gold standard for diagnosis of perianal fistulae in Crohn disease. However, this view has recently been challenged by Schwartz et al. who compared EUA, MRI, and EUS in a prospective blinded study of 34 patients with suspected Crohn perianal fistulae [49]. In this study, a consensus gold standard was determined for each patient. The authors observed a diagnostic accuracy exceeding $85 \%$ for all three modalities, specifically $91 \%$ for EUA and EUS and $87 \%$ for MRI. Of note, when any two of the tests were combined, diagnostic accuracy increased to $100 \%$.

\section{Medical Treatment}

\section{5-Aminosalicylic Acid Derivatives}

Although modestly efficacious in inducing remission in patients with mild-to-moderate Crohn disease, the treatment of Crohn fistulae with 5-aminosalicylic acid derivatives has never been studied in controlled trials. Thus, they cannot be recommended for the treatment of fistulizing Crohn disease.

\section{Corticosteroids}

There are no controlled studies evaluating the use of steroids in the management of Crohn fistulae. Unfortunately, neither the National Cooperative Crohn Disease trial nor the European Cooperative Crohn Disease trial provided data on response in the subgroup of patients with fistulae. However, two large uncontrolled studies have shown that corticosteroid use may actually be detrimental to patients with fistulizing Crohn disease, as it was associated with higher rates of surgical intervention [57, 58]. A recent retrospective case-control study of 432 patients with Crohn disease studied risk of intra-abdominal or pelvic abscess with systemic corticosteroid use during the previous 3 months [59]. The authors found a significant 9-fold increased risk of intraabdominal or pelvic abscess in patients with perforating Crohn disease who had received systemic corticosteroids during the prior 3 months (adjusted $\mathrm{OR}=9.03,95 \% \mathrm{CI}=2.40-33.98$ ). In patients with relapsed active disease, they also reported a significant 9-fold increased risk of abscess in patients receiving systemic steroids in the 3 months prior to presentation (unadjusted $\mathrm{OR}=9.31$, 95\% CI $=1.03-83.91$ ). For these reasons, corticosteroids should not be used in patients with fistulizing Crohn disease.

\section{Antibiotics}

Although antibiotics are the most commonly used medication for the treatment of fistulae in Crohn disease, there are no controlled data indicating that these agents are effective in this regard. The use of antibiotics in fistulizing Crohn disease is based upon a number of uncontrolled case series, each with a small number of patients [60-69]. Metronidazol, the most commonly used antibiotic, was first discovered in 1975 to have possible efficacy by Ursing and Kamme, who reported perianal fistula closure in 3 patients [60]. Five years later, Bernstein et al. treated 21 consecutive patients with perianal Crohn fistulae with metronidazol at a dose of $20 \mathrm{mg} / \mathrm{kg} / \mathrm{day}$ and observed clinical improvement in all patients, fistula closure in $83 \%$, and complete healing in $56 \%$ [61]. These responses typically occurred within 6-8 weeks of commencement of therapy. In 1982 , the same group published a follow-up study, comprised of 17 of the 21 original patients and 9 additional consecutive patients, and found that dosage reduction was associated with relapse in all patients [63]. However, rapid healing was noted in all patients upon readministration of metronidazol. Thus, while efficacious in the induction of improvement, metronidazol is limited in that maintenance therapy is often required. Three other small, uncontrolled studies have also observed efficacy with metronidazol in fistulizing Crohn disease with fistula closure rates of 
$40-50 \%$, but a high rate of relapse after cessation of therapy was seen in one of these studies [62, 64, 65]. The typical dose of metronidazol in the treatment of fistulizing Crohn disease ranges from 750-1500 mg/day. Adverse events associated with metronidazol are quite common, often leading to intolerance and discontinuation of the drug, and include a distal sensory neuropathy with paresthesias, nausea, dyspepsia, fatigue, glossitis, metallic taste, and a disulfiram-like reaction to alcohol ingestion [70].

Given that adverse events are commonly problematic with metronidazol, ciprofloxacin began to be used in the late 1980s and early 1990s to treat Crohn fistulae [66-69]. The first report of ciprofloxacin use in this setting was by Turunen et al. who studied 8 patients with severe perianal disease and 1 patient with enterocutaneous fistula refractory to metronidazol [66]. In this study, in which patients were given $1000-1500 \mathrm{mg} /$ day of ciprofloxacin for 3-12 months, the authors found that all patients demonstrated initial improvement, but 50\% continued to have persistent drainage, which required surgical intervention in several patients. As with metronidazol, relapses were common upon cessation of therapy, but improvement was seen upon reinstitution of therapy in most cases. A subsequent study, published only in abstract form by Wolf et al. noted improvement in 4 out of 5 patients with severe perianal disease within 5 weeks of treatment [67]. Combination therapy with ciprofloxacin and metronidazol has been examined by Solomon et al. in a retrospective study of 14 patients [68]. They observed improvement in 9 patients and fistula closure in 3 patients within 12 weeks, but like previous antibiotic studies, they also reported that relapse was the norm following discontinuation of therapy. The typical dose of ciprofloxacin in the treatment of fistulizing Crohn disease ranges from 1000-1500 mg/day. Adverse events with ciprofloxacin are uncommon and include headache, nausea, diarrhea, rash, and spontaneous tendon rupture [71, 72]. In pediatric population caution should be exercised regarding possible effect on developing musculoskeletal system due to toxicity observed in juvenile animal data.

To date, there has been no comparative study published comparing metronidazol and ciprofloxacin in the treatment of fistulizing Crohn disease. There is now a trial ongoing evaluating metronidazol versus ciprofloxacin versus placebo for Crohn fistula funded by the Crohn and Colitis Foundation of America.

\section{6-Mercaptopurine/Azathioprine}

No controlled trials examining fistula healing with 6-mercaptopurine (6-MP) or azathioprine as a primary endpoint have ever been published. In the very first publication documenting use of azathioprine in Crohn disease, Brooke et al. reported that all 6 patients with fistulizing disease who had received azathioprine demonstrated marked clinical improvement in their fistulae [73]. Since then, five randomized controlled trials, which investigated healing of fistulae as a secondary endpoint, have been published (Table 33.1) [74-78]. The studies used improvement or complete healing of fistulae as the outcome measure. With the exception of the trial by Present et al. the studies had very few patients with fistulizing disease. The studies were quite heterogeneous with respect to duration of therapy; there was also some variability in medication used and dosage. Three of the five trials observed higher rates of fistula improvement with 6-MP or azathioprine [75, 76, 78]. Of note, the study by Present et al. observed a 31\% rate of complete closure of the fistulae in the group receiving 6-MP versus $6 \%$ for the placebo group [78]. A meta-analysis of these five trials reported an overall response rate (defined as improvement or complete healing) in $54 \%$ of patients treated with 6-MP or azathioprine compared to $21 \%$ in patients treated with placebo [80]. The corresponding pooled odds ratio for fistula healing with 6-MP or azathioprine was $4.44(95 \% \mathrm{CI}=1.50-13.20)$. When interpreting the results of this meta-analysis, it is important to keep in mind that the majority of the fistulous cases (46 out of 70, or $66 \%$ ) were derived from a single study conducted at a single center [78]. Thus, the results of the meta-analysis were driven largely by that one study. Moreover, as mentioned previously, fistula healing was not a primary 
Table 33.1. Randomized controlled trials for treatment of fistulizing Crohn's disease with 6-MP or azathioprine.

\begin{tabular}{lcccccc}
\hline Author, Year & $\mathbf{N}$ & Drug, Dose & Rx Time & Response Drug & Response Placebo & P-value \\
\hline $\begin{array}{l}\text { Willoughby et al., } \\
1971 \text { [74] }\end{array}$ & 3 & $\begin{array}{r}\text { Azathioprine, } \\
2 \mathrm{mg} / \mathrm{kg} / \mathrm{d}\end{array}$ & $24 \mathrm{wk}$ & $0 / 2(0 \%)$ & $0 / 1(0 \%)$ & $\mathrm{NR}$ \\
$\begin{array}{l}\text { Rhodes et al., } \\
1971 \text { [75] }\end{array}$ & 6 & $\begin{array}{r}\text { Azathioprine, } \\
2 \mathrm{mg} / \mathrm{kg} / \mathrm{d}\end{array}$ & $2 \mathrm{mo}$ & $2 / 4(50 \%)$ & $0 / 2(0 \%)$ & $\mathrm{NR}$ \\
$\begin{array}{l}\text { Klein et al., } \\
1974 \text { [76] }\end{array}$ & 10 & $\begin{array}{r}\text { Azathioprine, } \\
3 \mathrm{mg} / \mathrm{kg} / \mathrm{d}\end{array}$ & $4 \mathrm{mo}$ & $4 / 5(80 \%)$ & $2 / 5(40 \%)$ & $\mathrm{NR}$ \\
$\begin{array}{l}\text { Rosenberg et al., } \\
1975 \text { [77] }\end{array}$ & 5 & $\begin{array}{r}\text { Azathioprine, } \\
2 \mathrm{mg} / \mathrm{kg} / \mathrm{d}\end{array}$ & $26 \mathrm{wk}$ & $0 / 4(0 \%)$ & $1 / 1(100 \%)$ & $\mathrm{NR}$ \\
$\begin{array}{l}\text { Present et al., } \\
1980 \text { [78] }\end{array}$ & 46 & $\begin{array}{r}\text { 6-MP, } 1.5 \\
\mathrm{mg} / \mathrm{kg} / \mathrm{d}\end{array}$ & $1 \mathrm{yr}$ & $16 / 29(55 \%)$ & $4 / 17(24 \%)$ & $\mathrm{NR}$ \\
\hline
\end{tabular}

Abbreviations: 6-MP, 6-mercaptopurine; N, number of patients; Rx, treatment; NR, not reported

endpoint for any of the individual trials. In addition, two uncontrolled case series, one in adults and one in children, have been published [80, 81]. The adult series, by Korelitz et al. treated 34 patients with 6-MP at a dose of $1.5 \mathrm{mg} / \mathrm{kg} /$ day with various types of fistulae, including perianal (18 patients), abdominal wall (8 patients), enteroenteric (7 patients), rectovaginal (6 patients), and vulvar (2 patients) [80]. Complete fistula closure was achieved in $39 \%$ of patients, with an additional $26 \%$ showing improvement. This study also underscored the importance of maintenance therapy. Fistulae remained closed for 1-5 years in $46 \%$ of patients (6 out of 13) who remained on 6-MP, and relapses tended to occur within 2 weeks to 9 months after discontinuation of the drug. Healing was once again achieved upon readministration of 6-MP. Furthermore, the authors noted that although all types of fistulae responded to 6-MP, abdominal wall and enteroenteric fistulae responded particularly well. The pediatric retrospective series evaluated 6-mercaptopurine or azathioprine therapy for fistulas, drainage, induration, and tenderness by Irvine Perianal Disease Activity Index score ranging from 0-20. Twenty patients met the study criteria and five (25\%) were considered treatment failures. Of the remaining 15 patients who were treated for minimum of six months, $67 \%$ had an improvement in drainage, $73 \%$ in tenderness, $60 \%$ in induration, and $40 \%$ in fistula closure. The mean Irvine PDAI was $7.67 \pm 2.19$ initially and $4.40 \pm 1.72$ after six months of therapy $(\mathrm{p}<0.001)$.

The combination of azathioprine and antibiotics has also been investigated. Recently, Dejaco et al. published a prospective, open-label study evaluating the use of an 8-week course of ciprofloxacin and/or metronidazol as a bridge to azathioprine in the treatment of 52 patients with perianal fistulae [82]. In this trial, 17 patients had been taking azathioprine prior the start of the study, and another 14 patients were initiated on azathioprine after the 8-week course of antibiotics. At week $8,50 \%$ of patients had improved and $25 \%$ had achieved complete healing. At week 20 , improvement was seen overall in $35 \%$ of patients with complete healing in $18 \%$. Patients who received azathioprine were significantly more likely to achieve response at week 20 than those who did not receive azathioprine $(48 \%$ vs. $15 \%, \mathrm{p}=.03)$. Thus, more evidence is provided that maintenance therapy is critical to continued fistula healing.

The cost-utility of the combination of metronidazol and 6-MP with or without infliximab has been studied by Arseneau et al. who designed a 1-year Markov model for therapy of perianal Crohn fistulae [83]. They observed that all treatment strategies had similar effectiveness, but strategies involving infliximab were much more expensive. Their conclusion, therefore, was that the incremental benefit of infliximab may not justify the higher cost over a 1-year period. Metronidazol combined with 6-MP appears to have the highest initial cost-utility in the treatment of fistulizing perianal Crohn disease. 
Typical doses of 6-MP and azathioprine used in clinical trials were $1-1.5 \mathrm{mg} / \mathrm{kg} / \mathrm{day}$ and 2-3 mg/kg/day, respectively. Currently, there is some debate as to whether dosing according to level of the active metabolites, the 6-thioguanine nucleotides, should be employed routinely. A recent meta-analysis has demonstrated that higher 6-thioguanine nucleotide levels (especially $\geq$ 230-260 pmol/10 ${ }^{8}$ red blood cells) were associated with clinical remission [84]. Adverse events are common with 6-MP and azathioprine, occurring in $9-15 \%$ of patients, and include allergic reactions, bone marrow suppression (especially leukopenia), pancreatitis, infection, hepatotoxicity, non-Hodgkin's lymphoma, and other gastrointestinal side effects (nausea, vomiting, and abdominal pain) [79, 85, 86].

\section{Methotrexate}

Methotrexate has been shown to be effective in the induction and maintenance of remission of Crohn disease in several controlled trials. Unfortunately, these studies did not address fistulizing disease. To date, only two retrospective case series have been published which examined the use of methotrexate for Crohn fistula [87, 88]. The first, by Vandeputte et al. analyzed 20 patients, 8 of whom had fistulae, refractory to azathioprine and requiring continuous corticosteroid treatment [87]. The authors reported improvement in $70 \%$ of patients overall with parenteral methotrexate within 12 weeks but did not specify the outcome of the patients with fistulae. The other series, by Mahadevan et al. included 37 courses of intramuscular and/or oral methotrexate given to 33 patients, 16 of whom had fistulae and were intolerant or refractory to 6-MP [88]. Complete fistula closure was achieved in $25 \%$ with another $31 \%$ showing improvement. Similar to other medications, fistulae often recurred when the dose of intramuscular methotrexate was decreased or when the route of administration was changed to oral. Thus, methotrexate may represent a reasonable alternative to patients who fail or cannot tolerate 6-MP or azathioprine, and long-term maintenance therapy is likely necessary; however, prospective randomized placebocontrolled trials are still needed to evaluate formally the efficacy of methotrexate for fistulizing Crohn disease. The initial dose of methotrexate suggested is $25 \mathrm{mg}$ intramuscularly every week. Concurrent administration of folate is advocated to lessen nausea. Adverse events are common and include hepatic fibrosis, bone marrow suppression, pneumonitis and pulmonary fibrosis, nausea, and teratogenicity [89, 90].

\section{Cyclosporine A}

There are no controlled trials documenting efficacy of cyclosporine for the treatment of fistulizing Crohn disease. To date, ten case series, with a total of 64 patients, assessing cyclosporine in Crohn fistula have been published [91-100]. The largest series, by Present and Lichtiger, looked at 16 patients with various types of Crohn fistulae (perianal, rectovaginal, and enterocutaneous) treated with intravenous cyclosporine at a dose of $4 \mathrm{mg} / \mathrm{kg} /$ day and observed improvement in $88 \%$ with complete fistula closure in $44 \%$ [95]. The mean time to response was rather short at just over 7 days. The authors noted that $36 \%$ of patients relapsed when converted to oral cyclosporine. Taken collectively, the ten case series showed an initial response rate of fistulizing Crohn disease to intravenous cyclosporine of $83 \%$ at doses of $2.5-5 \mathrm{mg} / \mathrm{kg} / \mathrm{day}$ (mostly $4 \mathrm{mg} / \mathrm{kg} / \mathrm{day}$ ). The overall rate of fistula recurrence after discontinuing oral cyclosporine was $62 \%$, however, and thus, most authorities will use cyclosporine as a bridge to other maintenance therapies, such as 6-MP or azathioprine [9, 26, 101]. The recommended initiation intravenous dose of cyclosporine is $4 \mathrm{mg} / \mathrm{kg} /$ day for one week, followed by oral formulation, typically $6-8$ $\mathrm{mg} / \mathrm{kg} / \mathrm{day}$, all dosed by levels. Adverse events are common and include paresthesias, hirsutism, hypertension, tremor, renal insufficiency, headache, opportunistic infections, gingival hyperplasia, seizures, and hepatotoxicity [89, 102]. 


\section{Tacrolimus}

Several uncontrolled case series, with a total of 16 patients with Crohn fistulae, have suggested that tacrolimus may have efficacy in the management of fistulizing disease [103-106]. The only controlled trial of tacrolimus for fistulizing Crohn disease is a randomized, double-blind, placebocontrolled study of 48 patients with perianal or enterocutaneous fistulae by Sandborn et al. [107]. In this study, patients received oral tacrolimus at $0.2 \mathrm{mg} / \mathrm{kg} / \mathrm{day}$ or placebo for 10 weeks. The primary endpoint, fistula improvement (defined as closure of $\geq 50 \%$ of draining fistulae and maintenance of closure for at least 4 weeks), occurred in $43 \%$ of patients receiving tacrolimus, compared to $8 \%$ of patients on placebo $(\mathrm{p}=.004)$. There was no difference in the secondary endpoint, fistula remission (defined as closure of all fistulae and maintenance of that closure for at least 4 weeks), between the two groups (10\% of tacrolimus-treated patients vs. $8 \%$ of placebo-treated patients). Of note, $38 \%$ of patients treated with tacrolimus developed increases in serum creatinine to $\geq 1.5 \mathrm{mg} / \mathrm{dL}$, necessitating dose reduction. Recently, Gonzalez-Lama et al. conducted a small, uncontrolled, prospective, open-label study of long-term oral tacrolimus at a dose of $0.1 \mathrm{mg} / \mathrm{kg} /$ day in 10 patients with Crohn fistulae refractory to all conventional therapy, including infliximab [108]. Patients in the study had perianal, enterocutaneous, and rectovaginal fistulae. The authors found that after 6-24 months of follow-up, 50\% of patients achieved complete response and an additional 40\% showed improvement. Importantly, no relapses and no cases of nephrotoxicity occurred throughout the follow-up period. In addition to nephrotoxicity, other adverse events associated with tacrolimus include headache, insomnia, paresthesias, tremor, and leg cramps [107].

\section{Infliximab}

Given that inflammation in Crohn disease is associated with high levels of tissue tumor necrosis factor- $\alpha$ (TNF- $\alpha)$ expression, therapies directed against this cytokine have become a recent focus of interest. Infliximab, a chimeric (75\% human, $25 \%$ murine) IgG1 monoclonal antibody directed against TNF- $\alpha$, is the prototype anti-TNF- $\alpha$ agent and has now become the cornerstone in medical therapy of fistulizing Crohn disease. Several uncontrolled studies have shown efficacy of infliximab in this regard [109-111]. Infliximab has also been shown to be efficacious in the treatment of Crohn fistula in two multicenter randomized, double-blind, placebo-controlled trials [112, 113]. The first, by Present et al. randomized 94 patients with draining abdominal (10\% of patients) or perianal (90\% of patients) fistulae to placebo, infliximab at a dose of $5 \mathrm{mg} / \mathrm{kg}$, or infliximab at $10 \mathrm{mg} / \mathrm{kg}$, administered intravenously at weeks 0,2 , and 6 [112]. The primary endpoint was a reduction in the number of draining fistulae by $\geq 50 \%$, which was maintained for at least 4 weeks, and a secondary endpoint was closure of all fistulae. The authors found that the primary endpoint was achieved in $68 \%$ of patients who received infliximab at $5 \mathrm{mg} / \mathrm{kg}$ and $56 \%$ of patients who received infliximab at $10 \mathrm{mg} / \mathrm{kg}$, compared to $26 \%$ of patients who received placebo $(\mathrm{p}=.002$ and $\mathrm{p}=.02$, respectively). Closure of all fistulae was achieved in $55 \%$ of patients who received infliximab at $5 \mathrm{mg} / \mathrm{kg}$ and $38 \%$ of patients who received infliximab at $10 \mathrm{mg} / \mathrm{kg}$, compared to only $13 \%$ of patients who received placebo $(\mathrm{p}=.001$ and $\mathrm{p}=.04$, respectively). The median time to response was 14 days for infliximab-treated patients vs. 42 days for patients assigned to placebo, and the majority of patients of infliximab-treated patients achieved fistula closure prior to the third infusion. Eleven percent of infliximab-treated patients developed a perianal abscess, possibly resulting from premature closure of the cutaneous end before closure of the rest of the fistula tract. However, the overall rates of infection did not differ between the infliximab and placebo groups.

In the study by Present et al. the median duration of response was three months, suggesting that, similar to the treatment of Crohn fistula with other medications, maintenance therapy may be required. In addition, since the treatment of luminal Crohn disease with infliximab often necessitates maintenance therapy, it should not come as a surprise that maintenance infliximab may 
be of benefit in the management of fistulizing Crohn disease. The other multicenter, randomized, double-blind, placebo-controlled trial of infliximab for Crohn fistula, the ACCENT II trial (A Crohn Disease Clinical Trial Evaluating Infliximab in a New Long-Term Treatment Regimen in Patients with Fistulizing Crohn Disease) reported by Sands et al. followed 282 patients with draining perianal, abdominal, and rectovaginal fistulae [113]. All patients were induced with infliximab at $5 \mathrm{mg} / \mathrm{kg}$ at weeks 0,2 , and 6 , and response, defined as a reduction in the number of draining fistulae by $\geq 50 \%$ for at least 4 weeks, was achieved in 195 patients (69\%), similar to the induction response rate reported by Present et al. At week 14, these 195 responders were then randomly assigned to receive infusions of either infliximab $5 \mathrm{mg} / \mathrm{kg}$ or placebo every 8 weeks until week 54 . The primary endpoint was time to loss of response. The authors observed a median time to loss of response of 40 weeks in infliximab-maintained patients vs. 14 weeks in placebo-assigned patients $(\mathrm{p}=.001)$. Overall, $42 \%$ of patients in the infliximab group had a loss of response, compared to $62 \%$ in the placebo group. At week $54,46 \%$ of patients treated with infliximab still had a response, versus $23 \%$ of patients treated with placebo $(\mathrm{p}=.001)$. In addition, at week $54,36 \%$ of patients in the infliximab group had a complete absence of draining fistulae, compared to $19 \%$ in the placebo group $(\mathrm{p}=.009)$. Sands et al. subsequently performed a post-hoc analysis of the ACCENT II data looking at the efficacy of infliximab induction and maintenance in the subset of women with rectovaginal fistulae [114]. Twenty-five of the original 138 women had a total of 27 draining rectovaginal fistulae at baseline. At week 14, 64\% of these 25 women had responded and were then randomized to receive infliximab or placebo maintenance therapy. The authors reported a median time to loss of response of 46 weeks for the infliximab group vs. 33 weeks in the placebo group.

The social impact of infliximab in patients with active fistulizing Crohn disease has also been investigated in two recent studies. Cadahia et al. were interested in the effect of infliximab induction treatment on health-related quality of life, and thus, they conducted a prospective observational study of 25 patients who received three-dose induction infliximab therapy for single or multiple draining abdominal or perianal fistulae [115]. The authors found that health-related quality of life, as measured by the SF-36, demonstrated significant improvement in the physical domain after 4 and 10 weeks. In addition, a significant increase in IBDQ score was seen after 4 weeks. More recently, Lichtenstein et al. evaluated the impact of infliximab maintenance therapy on the number of hospitalizations, surgeries, and procedures in patients with fistulizing Crohn disease [116]. Using data from the ACCENT II trial, they revealed that compared to patients who received placebo, patients who received maintenance infliximab had significantly fewer number of mean hospitalization days ( 0.5 vs. 2.5 days), hospitalizations (0.11 vs. 0.31$)$, total surgeries and procedures (65 vs. 126), inpatient surgeries and procedures (7 vs. 41 ), and major surgeries (2 vs. 11).

Mechanistically, infliximab's effects on mucosal cytokine profiles may predict which patients with fistulizing Crohn disease will relapse. Agnholt et al. recently collected tissue samples for cytokine analysis from 26 patients with Crohn fistulae [117]. They observed that fistula healing was associated with decreased production of TNF- $\alpha$, interferon- $\gamma$, and interleukin-10, while relapse was associated with increased production of interferon- $\gamma$.

Despite all of its reported success, the use of infliximab may not obviate the need for surgical management of Crohn fistulae in many cases. Poritz et al. retrospectively examined surgical rates in patients treated with infliximab for fistulizing Crohn disease at a single institution [118]. Among the 26 patients with various types of fistulae, $46 \%$ experienced a partial response to infliximab, and an additional $23 \%$ had fistula closure. However, $54 \%$ of patients overall still required surgery after infliximab therapy and another $23 \%$ continued to open fistulous drainage but refused surgery. Of note, none of the patients with either enterocutaneous or peristomal fistulae were healed with infliximab treatment. Moreover, as alluded to previously, infliximab therapy may not be the most cost-effective initial strategy in the management of Crohn perianal fistulae, according to the costutility analysis performed by Arseneau et al. [83]. Compared to the combination of 6-MP and 
metronidazol, any initial intervention involving infliximab resulted in an increase in incremental cost-utility by more than $\$ 350,000$ per quality-adjusted life year, due exclusively to the high cost of infliximab.

The effectiveness of infliximab in combination with other medical therapies for fistulizing Crohn disease has also been investigated in several studies [119-121]. West et al. conducted a double-blind, placebo-controlled trial of ciprofloxacin overlapping with infliximab in patients with perianal Crohn fistulae [119]. In this study, 24 patients were randomized to receive either ciprofloxacin at $1000 \mathrm{mg} /$ day or placebo for 12 weeks in addition to infliximab at $5 \mathrm{mg} / \mathrm{kg}$ at weeks 6,8 , and 12 . Patients were followed for 18 weeks, and the primary endpoint was reduction in the number of draining fistulae by $\geq 50 \%$. The authors reported that $73 \%$ of the ciprofloxacin-treated patients responded, compared to $39 \%$ in the placebo group. One caveat is that the response rate to infliximab alone was much less than in other infliximab studies, in which at least $60 \%$ of patients responded. Infliximab has also been evaluated in combination with immunomodulator therapy. Ochsenkühn et al. performed an uncontrolled pilot study of long-term 6-MP (at $1 \mathrm{mg} / \mathrm{kg} / \mathrm{day}$ ) or azathioprine (at $2-2.5 \mathrm{mg} / \mathrm{kg} / \mathrm{day}$ ) in combination with induction infliximab in 16 patients [120]. They found that $75 \%$ of patients achieved complete fistula closure which persisted for more than 6 months (median time of 10 months). As seen previously, the median time to fistula closure was 14 days. A similar uncontrolled pilot study by Schröder et al. followed 12 consecutive patients with Crohn fistulae intolerant or resistant to azathioprine [121]. Patients were treated with induction infliximab and long-term methotrexate at $20 \mathrm{mg} / \mathrm{week}$ (intravenously for 6 weeks, followed by oral thereafter). The authors observed that $33 \%$ of patients experienced complete fistula closure for at least 6 months (median 13 months), and 25\% had a partial response. While providing a suggestion of efficacy of combination therapy for treatment of fistulizing Crohn disease, controlled trials have yet to be performed.

The combination of infliximab with surgical intervention in the treatment of Crohn perianal fistulae has also been recently assessed in a several studies [6, 7, 122, 123]. Regueiro and Mardini retrospectively analyzed 32 consecutive patients with perianal Crohn fistulae, all of whom had received at least 3 induction doses of infliximab and some of whom had additionally undergone an EUA with seton placement prior to infliximab treatment [6]. Response was defined as complete closure and cessation of drainage from the fistula. They found that compared to patients treated with infliximab alone, patients who had a preinfusional EUA with seton placement had a significantly higher rate of initial response $(100 \%$ vs. $83 \%, \mathrm{p}=.014)$, lower rate of recurrence $(44 \%$ vs. $79 \%, \mathrm{p}=.001)$, and longer time to recurrence $(13.5$ months vs. 3.6 months, $\mathrm{p}=.0001)$. Another study, by van der Hagen et al. compared 10 patients treated with seton placement followed by infliximab to 7 patients treated with surgery alone in a retrospective review of consecutive patients with complex perianal fistulae [122]. After a median follow-up of 19 months, all patients achieved fistula healing. Fistula recurrence was seen in one patient $(10 \%)$ in the combined therapy group vs. two patients $(29 \%)$ in the surgery alone group. Two other case series have also documented favorable rates of fistula healing with seton placement followed by induction and maintenance infliximab, with complete and partial healing rates of $67 \%$ and $19 \%$, respectively, in one study [8] and 47\% and 53\%, respectively, in the other [123].

Adverse events with infliximab treatment are common and include infusion reactions, delayedtype hypersensitivity reactions, formation of human antichimeric antibodies (currently known as antibodies to infliximab [ATI]), formation of antinuclear and anti-double-stranded DNA antibodies, and drug-induced lupus-like reactions [124-126]. In addition, infectious complications seem to be increased, but serious infections, such as pneumonia, sepsis, tuberculosis, and opportunistic infections, including listeriosis, aspergillosis, histoplasmosis, coccidiomycosis, and Pneumocystis carinii pneumonia, occur only rarely [127-131]. Finally, there have been isolated case reports of hepatic necrosis and non-Hodgkin's lymphoma in patients treated with infliximab, although it has not been determined whether these events were the direct consequence of infliximab therapy. 


\section{Other Anti-TNF-alpha Agents}

Several other anti-TNF- $\alpha$ medications have shown promise in the treatment of fistulizing Crohn disease and may provide an alternative option for patients in whom infliximab either is not tolerated, has lost efficacy, or was never effective. Adalimumab, a fully human IgG1 monoclonal antibody, was investigated by Sandborn et al. in a recent pilot study of 24 patients with Crohn disease who had lost responsiveness or developed intolerance to infliximab [132]. In this 12-week, uncontrolled trial, patients received $80 \mathrm{mg}$ of subcutaneous adalimumab at week 0 , followed by $40 \mathrm{mg}$ every other week starting at week 2 . Nine patients in the study had fistulizing disease with open and draining perianal or enterocutaneous fistulae. The authors observed fistula improvement, defined as a reduction in the number of draining fistulae by $\geq 50 \%$, in 2 patients $(22 \%)$ at week 2, 4 patients $(44 \%)$ at week 4 , and 5 patients $(56 \%)$ at week 12 . Complete fistula closure was achieved in 1 patient (11\%) and week 2, 3 patients (33\%) at week 4, and 3 patients (33\%) at week 12 . Overall, among the 24 patients, $71 \%$ experienced adverse events, which were serious in only 2 patients $(8 \%)$ and required withdrawal in 1 patient with new-onset seizure. Reported adverse events included upper respiratory infection, headache, bronchitis, rash, fatigue, arthritic pain, abdominal pain, back ache, nausea, perianal abscess, numbness, and injection site reaction. However, since this study was not placebo-controlled, it is difficult to say which of these adverse reactions can be attributed directly to adalimumab.

CDP571, a humanized (95\% human, 5\% murine) IgG4 monoclonal antibody, has been also been assessed for efficacy in the treatment of Crohn fistulae in two multicenter, randomized, double-blind, placebo-controlled trials [133, 134]. The first study, by Feagan et al. published only in abstract form, treated 71 patients with steroid-dependent Crohn disease with intravenous CDP571 at $20 \mathrm{mg} / \mathrm{kg}$ or placebo at week 0 , followed by a second infusion of CDP571 at $10 \mathrm{mg} / \mathrm{kg}$ or placebo at week 8 [133]. At week 16, among the subgroup of patients with draining perianal fistulae, fistula closure was achieved in $25 \%$ of patients who received CDP571, compared to none in the placebo group. The other study, by Sandborn et al. followed 169 patients for 24 weeks, during which patients received an initial infusion of CDP571 at either $10 \mathrm{mg} / \mathrm{kg}$ or $20 \mathrm{mg} / \mathrm{kg}$ or placebo, followed by CDP571 at $10 \mathrm{mg} / \mathrm{kg}$ or placebo every $8-12$ weeks [134]. This study included 37 patients with open perianal or enterocutaneous fistulae and reported that $50 \%$ of patients treated with CDP571 achieved fistula closure vs. $15 \%$ of patients who received placebo. Adverse events due to CDP571 include infusion reactions, formation of anti-idiotype antibodies, development of new antinuclear or anti-double-stranded DNA antibodies, insomnia, pruritus, and rash [133, 134].

Thalidomide has also been preliminarily evaluated in the treatment of fistulizing Crohn disease in two open-label pilot studies [135, 136]. The first study, by Ehrenpreis et al. enrolled 22 patients with refractory Crohn disease to receive oral thalidomide at 200 or $300 \mathrm{mg} / \mathrm{day}$ for 12 weeks [135]. At week 4, of the 13 patients with fistulae, 9 patients $(69 \%)$ responded, 3 patients $(23 \%)$ achieved remission, and 2 patients $(15 \%)$ had closure of all fistulae. Nine patients with fistulizing disease completed the 12 weeks of treatment. Of these 9 patients, all (69\%) were responders, 6 patients (46\%) achieved remission, and 5 patients $(38 \%)$ had complete closure of all fistulae. The other pilot study, by Vasiliauskas et al. treated 12 patients with steroid-dependent Crohn disease with 50 or $100 \mathrm{mg} /$ day of thalidomide for 12 weeks [136]. Of the 6 patients with active perianal fistulae at the time of entry into the study, five (83\%) had improvement in symptoms after 4 weeks. Four of these 6 patients with fistulizing disease completed 12 weeks of treatment. Fistula closure was achieved in 1 patient (17\%) at week 12, with improvement in another 2 patients (33\%). Adverse events are common with thalidomide therapy and include severe somnolence, peripheral neuropathy, teratogenicity, peripheral edema, constipation, seborrheic dermatitis, hypertension, muscle spasm, and diffuse rash [135, 136].

\section{Novel Therapies}

A variety of other therapies for fistulizing Crohn disease have been suggested to be of possible benefit in uncontrolled case series or anecdotally. These include elemental diets, bowel rest with 
total parental nutrition, mycophenolate mofetil, granulocyte-colony stimulating factor, hyperbaric oxygen, and coagulation factor XIII [137-157]. However, controlled trials are required before any of these modalities can be recommended for routine use.

\section{Summary}

The treatment of perianal fistulizing Crohn disease has evolved greatly in the last fifteen years, due largely to improvements in medical therapy. Tables 33.2 and 33.3 summarize all published controlled and uncontrolled trials of immunomodulator and biological therapy for the treatment of Crohn fistulae. The advent of immunomodulators and anti-TNF- $\alpha$ agents has transformed the treatment of Crohn fistulae from almost exclusively surgical to placing a much larger emphasis on medical therapy, either as initial therapy alone, with surgery reserved for refractory cases, or

Table 33.2. Controlled trials for treatment of fistulizing Crohn's disease with immunomodulators and biological agents.

\begin{tabular}{|c|c|c|c|c|c|c|}
\hline Author, Year & $\mathbf{N}$ & Drug, Dose & Rx Time & $\begin{array}{l}\text { Response } \\
\text { Drug }\end{array}$ & $\begin{array}{l}\text { Response } \\
\text { Placebo }\end{array}$ & P-value \\
\hline \multicolumn{7}{|l|}{ Immunomodulators } \\
\hline $\begin{array}{l}\text { Azathioprine/6-MP } \\
\text { Willoughby et al., } \\
1971 \text { 74 }\end{array}$ & 3 & $\begin{array}{c}\text { Azathioprine, } \\
2 \mathrm{mg} / \mathrm{kg} / \mathrm{d}\end{array}$ & $24 \mathrm{wk}$ & $0 / 2(0 \%)$ & $0 / 1(0 \%)$ & NR \\
\hline $\begin{array}{l}\text { Rhodes et al., } \\
1971 \text { [75] }\end{array}$ & 6 & $\begin{array}{l}\text { Azathioprine, } \\
2 \mathrm{mg} / \mathrm{kg} / \mathrm{d}\end{array}$ & $2 \mathrm{mo}$ & $2 / 4(50 \%)$ & $0 / 2(0 \%)$ & NR \\
\hline $\begin{array}{l}\text { Klein et al., } \\
1974 \text { [76] }\end{array}$ & 10 & $\begin{array}{l}\text { Azathioprine, } \\
3 \mathrm{mg} / \mathrm{kg} / \mathrm{d}\end{array}$ & $4 \mathrm{mo}$ & $4 / 5(80 \%)$ & $2 / 5(40 \%)$ & NR \\
\hline $\begin{array}{l}\text { Rosenberg et al., } \\
1975 \text { [77] }\end{array}$ & 5 & $\begin{array}{l}\text { Azathioprine, } \\
2 \mathrm{mg} / \mathrm{kg} / \mathrm{d}\end{array}$ & $26 \mathrm{wk}$ & $0 / 4(0 \%)$ & $1 / 1(100 \%)$ & NR \\
\hline $\begin{array}{l}\text { Present et al., } \\
1980 \text { [78] }\end{array}$ & 46 & $\begin{array}{c}6-\mathrm{MP}, 1.5 \\
\mathrm{mg} / \mathrm{kg} / \mathrm{d}\end{array}$ & $1 \mathrm{yr}$ & $16 / 29(55 \%)$ & $4 / 17(24 \%)$ & NR \\
\hline Total & 70 & & & $22 / 44(50 \%)$ & $7 / 26(27 \%)$ & \\
\hline $\begin{array}{l}\text { Tacrolimus } \\
\text { Sandborn et al., } \\
2003 \text { [107] }\end{array}$ & 48 & $\begin{array}{l}\text { Tacrolimus, } \\
0.2 \mathrm{mg} / \mathrm{kg} / \mathrm{d}\end{array}$ & $10 \mathrm{wk}$ & $9 / 21(43 \%)$ & $2 / 25(8 \%)$ & .004 \\
\hline \multicolumn{7}{|l|}{ Biological agents } \\
\hline \multirow[t]{2}{*}{$\begin{array}{l}\text { Infliximab } \\
\text { Present et al., } \\
1999 \text { [112] }\end{array}$} & 94 & $\begin{array}{r}\text { Infliximab, } \\
5 \mathrm{mg} / \mathrm{kg}\end{array}$ & $14 \mathrm{wk}$ & $21 / 31(68 \%)$ & $8 / 31(26 \%)$ & .002 \\
\hline & & $\begin{array}{l}\text { Infliximab, } \\
10 \mathrm{mg} / \mathrm{kg}\end{array}$ & & $18 / 32(56 \%)$ & & .02 \\
\hline \multirow[t]{2}{*}{$\begin{array}{l}\text { Sands et al., } \\
2004 \text { [113] }\end{array}$} & 195 & $\begin{array}{l}\text { Infliximab, } \\
5 \mathrm{mg} / \mathrm{kg}\end{array}$ & $54 \mathrm{wk}$ & $42 / 91(46 \%)$ & $23 / 98(23 \%)$ & .001 \\
\hline & & & & $\begin{array}{l}\text { Time to loss of } \\
\text { response }=> \\
40 \mathrm{wk}\end{array}$ & $\begin{array}{l}\text { Time to } \\
\text { loss of } \\
\text { response } \\
=14 \mathrm{wk}\end{array}$ & $<.001$ \\
\hline Total & 289 & & & $81 / 154(53 \%)$ & $\begin{array}{l}31 / 129 \\
\quad(24 \%)\end{array}$ & \\
\hline \multicolumn{7}{|l|}{ CDP571 } \\
\hline $\begin{array}{l}\text { Sandborn et al., } \\
2001 \text { [134] }\end{array}$ & 37 & $\begin{array}{l}\text { CDP571, } \\
10 \text { or } \\
20 \mathrm{mg} / \mathrm{kg}\end{array}$ & $24 \mathrm{wk}$ & $12 / 24(50 \%)$ & $2 / 13(15 \%)$ & .074 \\
\hline
\end{tabular}

Abbreviations: N, number of patients; Rx, treatment; NR, not reported; 6-MP, 6-mercaptopurine 
Table 33.3. Uncontrolled trials for treatment of fistulizing Crohn disease with immunomodulators and biological agents.

\begin{tabular}{|c|c|c|c|c|}
\hline Author, Year & $\mathbf{N}$ & Drug, Dose & Initial Response & $\begin{array}{l}\text { Sustained } \\
\text { Response }\end{array}$ \\
\hline \multicolumn{5}{|l|}{ Immunomodulators } \\
\hline $\begin{array}{l}\text { Methotrexate } \\
\text { Mahadevan et al., } 2003 \text { [88] } \\
\text { Cyclosporin A }\end{array}$ & 16 & Methotrexate, $25 \mathrm{mg} / \mathrm{wk} \mathrm{im}$ & $9 / 16(56 \%)$ & $3 / 16(19 \%)$ \\
\hline Fukushima et al., 1989 [91] & 1 & Cyclosporin A, $8 \mathrm{mg} / \mathrm{kg} / \mathrm{d}$ po & $1 / 1(100 \%)$ & $1 / 1(100 \%)$ \\
\hline Lichtiger, 1990 [92] & 10 & Cyclosporin A, 4 mg/kg/d iv & $6 / 10(60 \%)$ & $\mathrm{NR}$ \\
\hline Markowitz et al., 1990 [93] & 1 & Cyclosporin A, $4 \mathrm{mg} / \mathrm{kg} / \mathrm{d}$ iv & $0 / 1(0 \%)$ & $0 / 1(0 \%)$ \\
\hline Hanauer et al., 1993 [94] & 5 & Cyclosporin A, $4 \mathrm{mg} / \mathrm{kg} / \mathrm{d}$ iv & $5 / 5(100 \%)$ & $2 / 5(40 \%)$ \\
\hline Present et al., 1994 [95] & 16 & Cyclosporin A, $4 \mathrm{mg} / \mathrm{kg} / \mathrm{d}$ iv & $14 / 16(88 \%)$ & $9 / 16(56 \%)$ \\
\hline Abreu-Martin et al., 1996 [96] & 2 & Cyclosporin A, $2.5 \mathrm{mg} / \mathrm{kg} / \mathrm{d}$ iv & $2 / 2(100 \%)$ & $1 / 2(50 \%)$ \\
\hline O’Neill et al., 1997 [97] & 8 & Cyclosporin A, 4 mg/kg/d iv & $7 / 8(88 \%)$ & $0 / 8(0 \%)$ \\
\hline Hinterleitner et al., 1997 [98] & 7 & Cyclosporin A, $5 \mathrm{mg} / \mathrm{kg} / \mathrm{d}$ iv & $9 / 9(100 \%)$ & $4 / 9(44 \%)$ \\
\hline Egan et al., 1998 [99] & 9 & Cyclosporin A, $4 \mathrm{mg} / \mathrm{kg} / \mathrm{d}$ iv & $7 / 9(78 \%)$ & $2 / 8(25 \%)$ \\
\hline Gurudu et al., 1999 [100] & 3 & Cyclosporin A, $4 \mathrm{mg} / \mathrm{kg} / \mathrm{d}$ iv & $2 / 3(67 \%)$ & NR \\
\hline Total & 64 & & $53 / 64(83 \%)$ & $19 / 50(38 \%)$ \\
\hline \multicolumn{5}{|l|}{ Biological agents } \\
\hline $\begin{array}{l}\text { Adalimumab } \\
\text { Sandborn et al., } 2004 \text { [132] }\end{array}$ & 9 & Adalimumab, 80/40 mg qow & $5 / 9(56 \%)$ & NR \\
\hline \multicolumn{5}{|l|}{ Thalidomide } \\
\hline Ehrenpreis et al., 1999 [135] & 13 & Thalidomide, 200 or $300 \mathrm{mg} / \mathrm{d}$ & $9 / 13(69 \%)$ & NR \\
\hline Vasiliauskas et al., 1999 [136] & 6 & Thalidomide, 50 or $100 \mathrm{mg} / \mathrm{d}$ & $1 / 6(17 \%)$ & NR \\
\hline Total & 19 & & $10 / 19(53 \%)$ & NR \\
\hline
\end{tabular}

Abbreviations: N, number of patients; NR, not reported; im, intramuscular; po, oral; iv, intravenous; qow, every other week

in combination with surgery from the start. For this reason, gastroenterologists and surgeons must work in concert in order to provide the best care for each patient. Proper fistula management also relies heavily on accurate diagnosis, especially defining the anatomy of the fistula, ascertaining whether abscess formation is present, and determining the location and extent of intestinal inflammation.

\section{References}

1. Crohn BB, Ginzburg L, Oppenheimer GD. Regional ileitis: a pathologic and clinical entity. JAMA 1932;99:1323-9.

2. Bissell AD. Localized chronic ulcerative colitis. Ann Surg 1934;99:957-66.

3. American Gastroenterological Association. American Gastroenterological Association medical position statement: perianal Crohn disease. Gastroenterology 2003;125:1503-7.

4. American Gastroenterological Association. AGA technical review on perianal Crohn disease. Gastroenterology 2003;125:1508-30.

5. Scott HJ, Northover JM. Evaluation of surgery for perianal Crohn fistulas. Dis Colon Rectum 1996;39:1039-43.

6. Regueiro M, Mardini H. Treatment of perianal fistulizing Crohn disease with infliximab alone or as an adjunct to exam under anesthesia with seton placement. Inflamm Bowel Dis 2003;9:98-103.

7. Topstad DR, Panaccione R, Heine JA, Johnson DR, MacLean AR, Buie WD. Combined seton placement, infliximab infusion, and maintenance immunosuppressives improve healing rates in fistulizing anorectal Crohn disease: a single center experience. Dis Colon Rectum 2003;46:577-83.

8. Bell SJ, Williams AB, Wiesel P, Wilkinson K, Cohen RC, Kamm MA. The clinical course of fistulating Crohn disease. Aliment Pharmacol Ther 2003;17:1145-51. 
9. Schwartz DA, Herdman CR. Review article: the medical treatment of Crohn perianal fistulas. Aliment Pharmacol Ther 2004;19:953-67.

10. Hughes L. Surgical pathology and management of anorectal Crohn disease. J R Soc Med 1978;71: 644-51.

11. Parks A. The pathogenesis and treatment of fistula-in-ano. Br Med J 1961;1:463-9.

12. Fielding JF. Perianal lesions in Crohn disease. J R Coll Surgeons Edinb 1972;17:32-7.

13. Greenstein AJ, Kark AE, Drelling DA. Crohn disease of the colon I. Fistula in Crohn disease colon, classification presenting features and management in 63 patients. Am J Gastroenterol 1974;62:419-29.

14. Farmer R, Hawk W, Turnbull RJ. Clinical patterns in Crohn disease. A statistical study of 615 cases. Gastroenterology 1975;68:627-35.

15. Rankin GB, Watts HD, Melnyk CS, Kelley ML Jr. National Cooperative Crohn Disease Study: extraintestinal manifestations and perianal complications. Gastroenterology 1979;77:914-20.

16. Buchmann P, Keighly MR, Allan RN, Thompson H, Alexander-Williams J. Natural history of perianal Crohn disease. Ten year follow-up: a plea for conservatism. Am J Surg 1980;140:642-4.

17. Williams DR, Coller JA, Corman ML, Nugent FW, Veidenheimer MC. Anal complications in Crohn disease. Dis Colon Rectum 1981;24:22-4.

18. Marks CG, Ritchie JK, Lockhart-Mummery HE. Anal fistulas in Crohn disease. Br J Surg 1981;68: $525-7$.

19. Hobbiss JH, Schofield PF. Management of perianal Crohn disease. J R Soc Med 1982;75:414-7.

20. Van Dongen LM, Lubbers E. Perianal fistulas in patients with Crohn disease. Arch Surg 1986;121:1187-90.

21. Goebell H. Perianal complications in Crohn disease. Neth J Med 1990;37:S47-51.

22. Hellers G, Bergstrand O, Ewerth S, Homstrom B. Occurrence and outcome after primary treatment of anal fistulae in Crohn disease. Gut 1980;21:525-7.

23. Schwartz DA, Loftus EV, Tremaine WJ, Pananccione R, Harmsen WS, Zinsmeister AR, Sandborn WJ. The natural history of fistulizing Crohn disease in Olmstead County, Minnesota. Gastroenterology 2002;122:875-80.

24. Gray BK, Lockhart-Mummery HE, Morson BC. Crohn disease of the anal region. Gut 1965;6:515-24.

25. Halme L, Sainio AP. Factors related to frequency, type, and outcome of anal fistulas in Crohn disease. Dis Colon Rectum 1995;38:55-9.

26. Judge TA, Lichtenstein GR. Treatment of fistulizing Crohn disease. Gastroenterol Clin N Am 2004;33:421-54.

27. Bayer I, Gordon PH. Selected operative management of fistula-in-ano in Crohn disease. Dis Colon Rectum 1994;37:760-5.

28. Makowiec F, Jehle EC, Becker HD, Starlinger M. Perianal abscess in Crohn disease. Dis Colon Rectum 1997;40:443-50.

29. Van Beers B, Grandin C, Kartheuser A. MRI of complicated anal fistulae: comparison with digital examination. J Comput Assist Tomogr 1994;18:87-90.

30. Fazio VW, Wilk P, Turnbull RB Jr, Jagelman DG. The dilemma of Crohn disease: ileosigmoidal fistula complicating Crohn disease. Dis Colon Rectum 1977;20:381-6.

31. Kuijpers HC, Schulpen T. Fistulography for fistula-in-ano. Is it useful? Dis Colon Rectum 1985;28:103-4.

32. Glass RE, Ritchie JK, Lennard-Jones JE, Hawley PR, Todd IP. Internal fistulas in Crohn disease. Dis Colon Rectum 1985;28:557-61.

33. Pomerri F, Pittarello F, Dodi G, Pianon P, Muzzio PC. [Radiologic diagnosis of anal fistulae with radio-opaque markers]. Radiologia Med 1988;75:632-7.

34. Weisman RI, Orsay CP, Pearl RK, Abcarian H. The role of fistulography in fistula-in-ano. Report of five cases. Dis Colon Rectum 1991;34:181-4.

35. Berliner L, Redmond P, Purow E, Megna D, Scottile V. Computed tomography in Crohn disease. Am J Gastroenterol 1982;77:584-53.

36. Goldberg HI, Gore RM, Margulis AR, Moss AA, Baker EL. Computed tomography in the evaluation of Crohn disease. Am J Roentgenol 1983;140:277-82.

37. Kerber GW, Greenberg M, Rubin JM. Computed tomography evaluation of local and extraintestinal complications of Crohn disease. Gastrointest Radiol 1984;9:143-8. 
38. Fishman EK, Wolf EJ, Jones B, Bayless TM, Siegelman SS. CT evaluation of Crohn disease: effect on patient management. Am J Roentgenol 1987;148:537-40.

39. Yousem DM, Fishman EK, Jones B. Crohn disease: perirectal and perianal findings at CT. Radiology 1988;167:331-4.

40. Van Outryve MJ, Pelckmans PA, Michielsen PP, Van Maercke YM. Value of tranrectal ultrasonography in Crohn disease. Gastroenterology 1991;101:1171-7.

41. Schratter-Sehn AU, Lochs H, Vogelsang H, Schurawitzki H, Herold C, Schratter M. Endoscopic ultrasonography versus computed tomography in the differential diagnosis of perianorectal complications in Crohn disease. Endoscopy 1993;25:582-6.

42. Koelbel G, Schmiedl U, Majer MC, Weber P, Jenss H, Kueper K, Hess CF. Diagnosis of fistulae and sinus tracts in patients with Crohn disease: value of MR imaging. Am J Roentgenol 1989;152: 999-1003.

43. Skalej M, Makowiec F, Weinlich M, Jenss H, Laniado M, Starlinger M. [Magnetic resonance imaging in perianal Crohn disease]. Dtsch Med Wochenschr 1993;118:1791-6.

44. Lunniss PJ, Barker PG, Sultan AH, Armstrong P, Reznek RH, Bartram CI, Cottam KS, Phillips RK. Magnetic resonance imaging of fistula-in-ano. Dis Colon Rectum 1994;37:708-18.

45. Barker PG, Lunniss PJ, Armstrong P, Reznek RH, Cottam KS, Phillips RK. Magnetic resonance imaging of fistula-in-ano: technique, interpretation, and accuracy. Clin Radiol 1994;49:7-13.

46. Haggert PJ, Moore NR, Shearman JD, Travis SP, Jewell DP, Mortensen NJ. Pelvic and perianal complications of Crohn disease: assessment using magnetic resonance imaging. Gut 1995;36: 407-10.

47. DeSouza NM, Hall AS, Puni R, Gilderdale DJ, Young IR, Kmiot WA. High resolution magnetic resonance imaging of the anal sphincter using a dedicated endoanal coil. Comparison of magnetic resonance imaging with surgical finding. Dis Colon Rectum 1996;39:926-34.

48. Spencer JA, Chapple K, Wilson D, Ward J, Windsor AC, Ambrose NS. Outcome after surgery for perianal fistula: predictive value of MR imaging. Am J Roentgenol 1998;171:403-6.

49. Schwartz DA, Wiersema MJ, Dudiak KM, Fletcher JG, Clain JE, Tremaine WJ, Zinsmeister AR, Norton ID, Boardman LA, Devine RM, Wolff BG, Young-Fadok TM, Diehl NN, Pemberton JH, Sandborn WJ. A comparison of endoscopic ultrasound, magnetic resonance imaging, and exam under anesthesia for evaluation of Crohn perianal fistulas. Gastroenterology 2001;121:1064-72.

50. Beets-Tan RG, Beets GL, van der Hoop AG, Kessels AG, Vliegen RF, Baeten CG, van Engelshoven JM. Preoperative MR imaging of anal fistulas: does it really help the surgeon? Radiology 2001;218: 75-84.

51. Tio TL, Mulder CJ, Wijers OB, Sars PR, Tytgat GN. Endosonography of peri-anal and per-colorectal fistula and/or abscess in Crohn disease. Gastrointest Endosc 1990;36:331-6.

52. Wijers O, Tio T, Tytgat G. Endosonography (transrectal and transvaginal) in the assessment of perianorectal fistulas and abscesses: experience with 127 cases. In: Demling L, Fruhmorgan P, eds. Non-neoplastic diseases of the anorectum. Kluwer, London, 1992;65-78.

53. Solomon MJ. Fistulae and abscesses in symptomatic perianal Crohn disease. Int J Colorectal Dis 1996;11:222-6.

54. Orsoni P, Barthet M, Portier F, Panuel M, Desjeux A, Grimaud JC. Prospective comparison of endosonography, magnetic resonance imaging and surgical findings in anorectal fistula and abscess complicating Crohn disease. Br J Surg 1999;86:360-4.

55. Stewart LK, McGee J, Wilson SR. Transperineal and transvaginal sonography of perianal inflammatory bowel disease. Am J Roentgenol 2001;177:627-32.

56. Sloots CE, Felt-Bersma RJ, Poen AC, Cuesta MA, Meuwissen SG. Assessment and classification of fistula-in-ano in patients with Crohn disease by hydrogen peroxide enhanced transanal ultrasound. Int J Colorectal Dis 2001;16:292-7.

57. Sparberg M, Kirsner JB. Long-term corticosteroid therapy for regional enteritis: an analysis of 58 courses in 54 patients. Am J Dig Dis 1966;11:865-80.

58. Jones JH, Lennard-Jones JF. Corticosteroids and corticotropin in the treatment of Crohn disease. Gut 1966;7:181-7.

59. Agrawal A, Durrani S, Leiper K, Ellis A, Morris AI, Rhodes JM. Effect of systemic corticosteroid therapy on risk for intra-abdominal or pelvic abscess in non-operated Crohn disease. Clin Gastroenterol Hepatol 2005;3:1215-20. 
60. Ursing B, Kamme C. Metronidazol for Crohn disease. Lancet 1975;1:775-7.

61. Bernstein LH, Frank MS, Brandt LJ, Boley SJ. Healing of perianal Crohn disease with metronidazol. Gastroenterology 1980;79:357-65.

62. Schneider MU, Strobel S, Riemann JF, Demling L. [Treatment of Crohn disease with metronidazol]. Dtsch Med Wochenschr 1981;106:1126-9.

63. Brandt LJ, Bernstein LH, Boley SJ, Frank MS. Metronidazol therapy for perianal Crohn disease: a follow-up study. Gastroenterology 1982;83:383-7.

64. Jakobovits J, Schuster MM. Metronidazol therapy for Crohn disease and associated fistulae. Am J Gastroenterol 1984;79:533-40.

65. Schneider MU, Laudage G, Guggenmoos-Holzmann I, Riemann JF. [Metronidazol in the treatment of Crohn disease. Results of a controlled randomized prospective study]. Dtsch Med Wochenschr 1985;110:1724-30.

66. Turunen U, Farkkila M, Seppala K. Long-term treatment of perianal or fistulous Crohn disease with ciprofloxacin. Scand J Gastroenterol Suppl 1989;24:144.

67. Wolf JL. Ciprofloxacin may be useful in Crohn disease (abstr). Gastroenterology 1990;98:A212.

68. Solomon MJ, McLeod RS, O'Connor BI, Steinhart AH, Greenberg GR, Cohen Z. Combination ciprofloxacin and metronidazol in severe perianal Crohn disease. Can J Gastroenterol 1993;7:571-3.

69. Turunen U, Farkkila M, Valtonen V. Long-term outcome of ciprofloxacin treatment in severe perianal or fistulous Crohn disease (abstr). Gastroenterology 1993;104:A793.

70. Freeman CD, Klutman NE, Lamp KC. Metronidazol. A therapeutic review and update. Drugs 1997;54:679-708.

71. Davis R, Markham A, Balfour JA. Ciprofloxacin. An updated review of its pharmacology, therapeutic efficacy and tolerability. Drugs 1996;51:1019-74.

72. Casparian JM, Luchi M, Moffat RE, Hinthorn D. Quinolones and tendon ruptures. South Med J 2000;93:488-91.

73. Brooke BN, Hoffman DC, Swarbrick ET. Azathioprine for Crohn disease. Lancet 1969;2:612-4.

74. Willoughby JM, Beckett J, Kumar PJ, Dawson AM. Controlled trial of azathioprine in Crohn disease. Lancet 1971;2:944-7.

75. Rhodes J, Bainton D, Beck P, Campbell H. Controlled trial of azathioprine in Crohn disease. Lancet 1971;2:1273-6.

76. Klein M, Binder HJ, Mitchell M, Aaronson R, Spiro H. Treatment of Crohn disease with azathioprine: a controlled evaluation. Gastroenterology 1974;66:916-22.

77. Rosenberg JL, Levin B, Wall AJ, Kirsner JB. A controlled trial of azathioprine in Crohn disease. Am J Digest Dis 1975;20:721-6.

78. Present DH, Korelitz BI, Wisch N, Glass JL, Sachar DB, Pasternack BS. Treatment of Crohn disease with mercaptopurine. A long-term, randomized, double-blind study. N Engl J Med 1980;302:981-7.

79. Pearson D, May G, Fick G, Sutherland L. Azathioprine and 6-mercaptopurine in Crohn disease: a meta analysis. Ann Intern Med 1995;123:132-42.

80. Korelitz BI, Present DH. Favorable effect of mercaptopurine on fistulae of Crohn disease. Digest Dis Sci 1985;30:58-64.

81. Jeshion WC, Larsen KL, Jawad AF, Piccoli DA, Verma R, Maller ES, Baldassano RN. Azathioprine and 6-mercaptopurine for the treatment of perianal Crohn disease in children. J Clin Gastroenterol 2000;30:294-8.

82. Dejaco C, Harrer M, Waldhoer T, Miehsler W, Vogelsang H, Reinisch W. Antibiotics and azathioprine for the treatment of perianal fistulas in Crohn disease. Aliment Pharmacol Ther 2003;18:1113-20.

83. Arseneau KO, Cohn SM, Cominelli F, Connors AF Jr. Cost-utility of initial medical management for Crohn disease perianal fistulae. Gastroenterology 2001;120:1640-56.

84. Osterman MT, Kundu R, Lichtenstein GR, Lewis JD. Association of 6-thioguanine nucleotide levels and inflammatory bowel disease activity: a meta-analysis. Gastroenterology 2006;130:1047-53.

85. Present DH, Meltzer SJ, Krumholz MP, Wolke A, Korelitz BI. 6-Mercaptopurine in the management of inflammatory bowel disease: short- and long-term toxicity. Ann Intern Med 1989;111:641-9.

86. Dayharsh GA, Loftus EV Jr, Sandborn WJ, Tremaine WJ, Zinsmeister AR, Witzig TE, Macon WR, Burgart LJ. Epstein-Barr virus-positive lymphoma in patients with inflammatory bowel disease treated with azathioprine or 6-mercaptopurine. Gastroenterology 2002;122:72-7. 
87. Vandeputte L, D'Haens G, Beart F, Rutgeerts P. Methotrexate in refractory Crohn disease. Inflamm Bowel Dis 1999;5:11-5.

88. Mahadevan U, Marion JF, Present DH. Fistula response to methotrexate in Crohn disease: a case series. Aliment Pharmacol Ther 2003;18:1003-8.

89. Sandborn WJ. A review of immune modifier therapy for inflammatory bowel disease: azathioprine, 6-mercaptopurine, cyclosporine, and methotrexate. Am J Gastroenterol 1996;91:423-33.

90. Lemann M, Zenjari T, Bouhnik Y, Cosnes J, Mesnard B, Rambaud JC. Methotrexate in Crohn disease: long-term efficacy and toxicity. Am J Gastroenterol 2000;95:1730-4.

91. Fukushima T, Sugita A, Masuzawa S, Yamazaki Y, Tsuchiya S. Effects of cyclosporine A on active Crohn disease. Gastroenterol Jpn 1989;24:12-5.

92. Lichtiger S. Cyclosporin therapy in inflammatory bowel disease: open-label experience. Mt Sinai J Med 1990;57:315-9.

93. Markowitz J, Rosa J, Grancher K, Aiges H, Daum F. Long-term 6-mercaptopurine treatment in adolescents with Crohn disease. Gastroenterology 1990;99:1347-51.

94. Hanauer SB, Smith MB. Rapid closure of Crohn disease fistulas with continuous intravenous cyclosporin A. Am J Gastroenterol 1993;88:646-9.

95. Present DH, Lichtiger S. Efficacy of cyclosporine in treatment of fistula of Crohn disease. Dig Dis Sci 1994;39:374-80.

96. Abreu-Martin J, Vasilauskas E, Gaiennie J, Voigt B, Targan SR. Continuous infusion cyclosporine is effective for acute severe Crohn disease...but for how long (abstr)? Gastroenterology 1996;110:A851.

97. O’Neill J, Pathmakanthan S, Goh J, Costello S. MacMathuna P, O'Connell R, Crowe J, Lennon J. Cyclopsorine A induces remission in fistulous Crohn disease but relapses occur upon cessation of treatment (abstr). Gastroenterology 1997;112:A1056.

98. Hinterleitner TA, Petritsch W, Aichbichler B, Fickert P, Ranner G, Krejs GJ. Combination of cyclosporine, azathioprine and prednisone for perianal fistulas in Crohn disease. Z Gastroenterol 1997;35:603-8.

99. Egan LJ, Sandborn WJ, Tremaine WJ. Clinical outcome following treatment of refractory inflammatory and fistulizing Crohn disease with intravenous cyclosporine. Am J Gastroenterol 1998;93:442-8.

100. Gurudu SR, Griffel LH, Gialanella RJ, Das KM. Cyclosporine therapy in inflammatory bowel disease: short- and long-term results. J Clin Gastroenterol 1999;29:151-4.

101. Present DH. Crohn fistula: current concepts in management. Gastroenterology 2003;124:1629-35.

102. Sandborn WJ. A critical review of cyclosporine therapy in inflammatory bowel disease. Inflamm Bowel Dis 1995;1:48-63.

103. Sandborn WJ. Preliminary report on the use of oral tacrolimus (FK506) in the treatment of complicated proximal small bowel and fistulizing Crohn disease. Am J Gastroenterol 1997;92:876-9.

104. Fellerman K, Ludwig D, Stahl M, David-Walek T, Stange EF. Steroid-unresponsive acute attacks of inflammatory bowel disease: immunomodulation by tacrolimus (FK506). Am J Gastroenterol 1998;93:1860-6.

105. Lowry PW, Weaver AL, Tremaine WJ, Sandborn WJ. Combination therapy with oral tacrolimus (FK506) and azathioprine or 6-mercaptopurine for treatment-refractory Crohn disease perianal fistulae. Inflamm Bowel Dis 1999;5:239-45.

106. Ierardi E, Principi M, Rendina M, Francavilla R, Ingrosso M, Pisani A, Amoruso A, Panella C, Francavilla A. Oral tacrolimus (FK506) in Crohn disease complicated by fistulae of the perineum. J Clin Gastroenterol 2000;125:30:200-2.

107. Sandborn WJ, Present DH, Isaacs KL, Wolf DC, Greenberg E, Hanauer SB, Feagan BG, Mayer L, Johnson T, Galanko J, Martin C, Sandler RS. Tacrolimus for the treatment of fistulas in patients with Crohn disease: a randomized, placebo-controlled trial. Gastroenterology 2003;125:380-88.

108. Gonzalez-Lama Y, Abreu L, Vera MI, Pastrana M, Tabernero S, Revilla J, Duran JG, Escartin P. Long-term oral tacrolimus therapy in refractory to infliximab fistulizing Crohn disease: a pilot study. Inflamm Bowel Dis 2005;11:8-15.

109. Cohen RD, Tsang JF, Hanauer SB. Infliximab in Crohn disease: first anniversary clinical experience. Am J Gastroenterol 2000;95:3469-77.

110. Farrell RJ, Shah SA, Lodhavia PJ, Alsahli M, Falchuk KR, Michetti P, Peppercorn MA. Clinical experience with infliximab therapy in 100 patients with Crohn disease. Am J Gastroenterol 2000;95:3490-7. 
111. Ricart E, Panaccione R, Loftus EV, Tremaine WJ, Sandborn WJ. Infliximab for Crohn disease in clinical practice at the Mayo Clinic: the first 100 patients. Am J Gastroenterol 2001;96:722-9.

112. Present DH, Rutgeerts P, Targan S, Hanauer SB, Mayer L, van Hogezand RA, Podolsky DK, Sands BE, Braakman T, DeWoody KL, Schaible TF, van Deventer SJH. Infliximab for the treatment of fistulas in patients with Crohn disease. N Engl J Med 1999;340:1398-405.

113. Sands BE, Anderson FH, Bernstein CN, Chey WY, Feagan BG, Fedorak RN, Kamm MA, Korzenik JR, Lashner BA, Onken JE, Rachmilewitz D, Rutgeerts P, Wild G, Wolf DC, Marsters PA, Travers SB, Blank MA, van Deventer SJ. Infliximab maintenance therapy for fistulizing Crohn disease. N Engl J Med 2004;350:876-85.

114. Sands BE, Blank MA, Patel K, van Deventer SJ. Long-term treatment of rectovaginal fistulas in Crohn disease: response to infliximab in the ACCENT II study. Clin Gastroenterol Hepatol 2004;2:912-20.

115. Cadahia V, Garcia-Carbonero A, Vivas S, Fuentes D, Nino P, Rebollo P, Rodrigo L. Infliximab improves quality of life in the short-term in patients with fistulizing Crohn disease in clinical practice. Rev Esp Enferm Dig 2004;96:369-74.

116. Lichtenstein GR, Yan S, Bala M, Blank M, Sands BE. Infliximab maintenance treatment reduces hospitalization, surgeries, and procedures in fistulizing Crohn disease. Gastroenterology 2005;128: 862-9.

117. Agnholt J, Dahlerup JF, Buntzen S, Tøttrup A, Lyhne Nielsen S, Lundorf E. Response, relapse and mucosal immune regulation after infliximab treatment in fistulating Crohn disease. Aliment Pharmacol Ther 2003;17:703-10.

118. Poritz LS, Rowe WA, Koltun WA. Remicade does not abolish the need for surgery in fistulizing Crohn disease. Dis Colon Rectum 2002;45:771-5.

119. West RL, van der Woude CJ, Hansen BE, Felt-Bersma RJF, van Tilburg AJP, Drapers JAG, Kuipers EJ. Clinical and endosonographic effect of ciprofloxacin on the treatment of perianal fistulae in Crohn disease with infliximab: a double-blind placebo-controlled study. Aliment Pharmacol Ther 2004;20:1329-36.

120. Ochsenkühn T, Göke B, Sackmann M. Combining infliximab with 6-mercaptopurine/azathioprine for fistula therapy in Crohn disease. Am J Gastroenterol 2002;97:2022-5.

121. Schröder O, Blumenstein I, Schulte-Buckholt A, Stein J. Combining infliximab and methotrexate in fistulizing Crohn disease resistant or intolerant to azathioprine. Aliment Pharmacol Ther 2004;19: 295-301.

122. Van der Hagen SJ, Baeten CG, Soeters PB, Russel MGVM, Beets-Tan RG, van Gemert WG. AntiTNF- $\alpha$ (infliximab) used as induction treatment in case of active proctitis in a multistep strategy followed by definitive surgery of complex anal fistulas in Crohn disease: a preliminary report. Dis Colon Rectum 2005;48:758-67.

123. Talbot C, Sagar PM, Johnston MJ, Finan PJ, Burke D. Infliximab in the surgical management of complex fistulating anal Crohn disease. Colorectal Disease 2005;7:164-8.

124. Sandborn WJ, Hanauer SB. Antitumor necrosis factor therapy for inflammatory bowel disease: a review of agents, pharmacology, clinical results, and safety. Inflamm Bowel Dis 1999;5:119-33.

125. Schaible TF. Long-term safety of infliximab. Can J Gastroenterol 2000;14:29C-32C.

126. Remicade (infliximab) for IV injection. Package Insert, 2002.

127. Keane J, Gershon S, Wise RP, Mirabile-Levens E, Kasznica J, Schwieterman WD, Siegel JN, Braun MM. Tuberculosis associated with infliximab, a tumor necrosis factor alpha-neutralizing agent. N Engl J Med 2001;345:1098-104.

128. Morelli J, Wilson FA. Does administration of infliximab increase susceptibility to listeriosis? Am J Gastroenterol 2000;95:841-2.

129. Kamath BM, Mamula P, Baldassano RN, Markowitz JE. Listeria meningitis after treatment with infliximab. J Pediatr Gastroenterol Nutr 2002;34:410-2.

130. Warris A, Bjorneklett A, Gaustad P. Invasive pulmonary aspergillosis associated with infliximab therapy. N Engl J Med 2001;344:1099-100.

131. Nakelchik M, Mangino JE. Reactivation of histoplasmosis after treatment with infliximab. Am J Med 2002;112:78.

132. Sandborn WJ, Hanauer SB, Loftus EV Jr, Tremaine WJ, Kane S, Cohen R, Hanson K, Johnson T, Schmitt D, Jeche R. An open-label study of the human anti-TNF monoclonal antibody adalimumab in subjects with prior loss of response or intolerance to infliximab for Crohn disease. Am J Gastroenterol 2004;99:1984-9. 
133. Feagan BG, Sandborn WJ, Baker JP, Cominelli F, Sutherland LR, Elson CD, Salzberg B, Archambault A, Bernstein CN, Lichtenstein GR, Heath PK, Hanauer SB. A randomized, double-blind, placebocontrolled multicenter trial of the engineered human antibody to TNF (CDP571) for steroid sparing and maintenance of remission in patients with steroid-dependent Crohn disease (abstr). Gastroenterology 2000;118:A655.

134. Sandborn WJ, Feagan BG, Hanauer SB, Present DH, Sutherland LR, Kamm MA, Wolf DC, Baker JP, Hawkey C, Archambault A, Bernstein CN, Novak C, Heath PK, Targan SR. An engineered human antibody to TNF (CDP571) for active Crohn disease: a randomized double-blind placebo-controlled trial. Gastroenterology 2001;120:1330-8.

135. Ehrenpreis ED, Kane SV, Cohen LB, Cohen RD, Hanauer SB. Thalidomide therapy for patients with refractory Crohn disease: an open-label trial. Gastroenterology 1999;117:1271-7.

136. Vasilauskas EA, Kam LY, Abreu-Martin MT, Hassard PV, Papadakis KA, Yang H, Zeldis JB, Targan SR. An open-label pilot study of low-dose thalidomide in chronically active, steroid-dependent Crohn disease. Gastroenterology 1999;117:1278-87.

137. Voitk AJ, Echave V, Brown RA, Gurd FN. Use of elemental during the adaptive stage of short gut syndrome. Gastroenterology 1973;65:419-26.

138. Segal AW, Levi AJ, Loewi G. Levamisole in the treatment of Crohn disease. Lancet 1977;2:382-5.

139. Axelsson C, Jarnum S. Assessment of the therapeutic value of an elemental diet in chronic inflammatory bowel disease. Scand J Gastroenterol 1977;12:89-95.

140. Russell RI, Hall MJ. Elemental diet therapy in the management of complicated Crohn disease. Scott Med J 1979;24:291-5.

141. Calam J, Crooks PE, Walker RJ. Elemental diets in the management of Crohn perianal fistulae. J Parenter Enteral Nutr 1980;4:4-8.

142. Jones VA. Comparison of total parenteral nutrition and elemental diet in induction of remission of Crohn disease. Dig Dis Sci 1987;32:100S-107S.

143. Fukuda Y, Kosaka T, Okui M, Hirakawa H, Shimoyama T. Efficacy of nutritional therapy for active Crohn disease. J Gastroenterol 1995;30:83-7.

144. Harford FJ, Fazio VW. Total parenteral nutrition as primary therapy for inflammatory bowel disease of the bowel. Dis Colon Rectum 1978;21:555-7.

145. Milewski PJ, Irving MH. Parenteral nutrition in Crohn disease. Dis Colon Rectum 1980;23:395-400.

146. Greenberg GR, Fleming CR, Jeejeebhoy KN, Rosenberg IH, Sales D, Tremaine WJ. Controlled trial of bowel rest and nutritional support in the management of Crohn disease. Gut 1988;29: 1309-15.

147. Fickert P, Hinterleitner TA, Wenzl HH, Aichbichler BW, Petritsch W. Mycopheylate mofetil in patients with Crohn disease. Am J Gastroenterol 1998;93:2529-32.

148. Vaughan D, Drumm B. Treatment of fistulas with granulocyte colony-stimulating factor in a patient with Crohn disease. N Engl J Med 1999;340:239-40.

149. Korzenik J, Dieckgraefe B. Immunostimulation in Crohn disease: results of a pilot study of G-CSF (R-Methug-CSF) in mucosal and fistulizing Crohn disease (abstr). Gastroenterology 2000; 118:A874.

150. Dieckgraefe BK, Korzenik JR. Treatment of active Crohn disease with recombinant human granulocytemacrophage colony-stimulating factor. Lancet 2002;360:1478-80.

151. Brady CE III, Cooley BJ, Davis JC. Healing of severe perianal and cutaneous Crohn disease with hyperbaric oxygen. Gastroenterology 1989;97:756-60.

152. Nelson EW Jr, Bright DE, Villar LF. Closure of refractory perianal Crohn lesion. Integration of hyperbaric oxygen into case management. Dig Dis Sci 1990;35:1561-6.

153. Brady CE III. Hyperbaric oxygen and perianal Crohn disease: a follow-up. Gastroenterology 1993;105:1264.

154. Lavy A, Weisz G, Adir Y, Ramon Y, Melamed Y, Eidelman S. Hyperbaric oxygen for perianal Crohn disease. J Clin Gastroenterol 1994;19:202-5.

155. Colombel JF, Mathieu D, Bouault JM, Lesage X, Zavadil P, Quandalle P, Cortot A. Hyperbaric oxygen in severe perianal Crohn disease. Dis Colon Rectum 1995;38:609-14.

156. Oshitani N, Nakamura S, Matsumoto T, Kobayashi K, Kitano A. Treatment of Crohn disease fistulas with coagulation factor XIII. Lancet 1996;347:119-20.

157. Teahon K, Bjarnason I, Pearson M, Levi AJ. Ten years' experience with an elemental diet in the management of Crohn disease. Gut 1990;31:1133-7. 